\title{
Hepatitis $C$ core antigen testing to diagnose active hepatitis $C$ infection among haemodialysis patients
}

Xue Zheng Wong ${ }^{1}$, Chye Chung Gan ${ }^{1}$, Rosmawati Mohamed ${ }^{1}$, Rosnawati Yahya², Shubash Ganapathy ${ }^{3}$, Soek Siam $\operatorname{Tan}^{4}$ and Soo Kun Lim ${ }^{1,5^{*}}$ (D)

\begin{abstract}
Background: Hepatitis C virus (HCV) infects more than 71 million people worldwide and chronic HCV infection increases the risk of liver cirrhosis and failure. Haemodialysis (HD) is one of the renal replacement therapies with risk of HCV transmission. Anti-HCV antibodies are the serological screening test for HCV infection that does not detect active phase of infection. Majority HCV infected HD patients in Malaysia do not have further HCV RNA performed due to high cost and thus HCV treatment is less frequently offered. HCV Core Antigen (HCV Ag) can potentially be used to diagnose active HCV infection in HD population in comparison to HCV RNA, at lower cost.

Methods: We conducted a cross-sectional study to assess the correlation between HCV Ag and HCV RNA and to identify the prevalence of active HCV infection among HCV seropositive HD patients from dialysis centres across West Malaysia from July 2019 to May 2020. Pre-dialysis blood was taken and tested for both HCV Ag and HCV RNA tests. HCV Ag was tested with Abbott ARCHITECT HCV Ag test.

Results: We recruited 112 seropositive HD patients from 17 centres with mean age of $54.04 \pm 11.62$ years, HD vintage of $14.1 \pm 9.7$ years, and male constitute $59.8 \%$ (67) of the study population. HCV Ag correlates well with HCV RNA (Spearman test coefficient $0.833, p<0.001$ ). The sensitivity was $90.7 \%$, specificity $100 \%$, positive predictive value (PPV) 100\%, negative predictive value (NPV) 76.5\%, and accuracy 92.9\%. For HCV RNA level $>3000 \mathrm{IU} / \mathrm{mL}, \mathrm{HCV}$ Ag had a higher sensitivity of $95.1 \%$ and greater correlation (Spearman test coefficient $0.897, p<0.001$ ). The prevalence of active HCV infection was $76.8 \%$ among HCV seropositive HD patients.

Conclusions: Although HCV Ag is less sensitive, it shows an excellent correlation with HCV RNA and has 100\% PPV. HCV Ag can be considered as an alternative diagnostic tool for chronic active HCV infection among HD cohort, who can then be considered for HCV treatment. For seropositive HD patient with negative HCV Ag, we recommend to follow-up with HCV RNA test.
\end{abstract}

Keywords: Abbott ARCHITECT HCV Ag, HCV Core antigen, Hepatitis C virus, HCV RNA, Haemodialysis

\footnotetext{
* Correspondence: limsk@ummc.edu.my

${ }^{1}$ Department of Medicine, Faculty of Medicine, University of Malaya, Jalan University, 50603 Kuala Lumpur, Malaysia

${ }^{5} 8 \mathrm{TE}$, Menara Timur, Pusat Perubatan Universiti Malaya, Jalan Universiti, Lembah Pantai, 50603 Kuala Lumpur, Malaysia

Full list of author information is available at the end of the article
}

(c) The Author(s). 2020 Open Access This article is licensed under a Creative Commons Attribution 4.0 International License, which permits use, sharing, adaptation, distribution and reproduction in any medium or format, as long as you give appropriate credit to the original author(s) and the source, provide a link to the Creative Commons licence, and indicate if changes were made. The images or other third party material in this article are included in the article's Creative Commons licence, unless indicated otherwise in a credit line to the material. If material is not included in the article's Creative Commons licence and your intended use is not permitted by statutory regulation or exceeds the permitted use, you will need to obtain permission directly from the copyright holder. To view a copy of this licence, visit http://creativecommons.org/licenses/by/4.0/ The Creative Commons Public Domain Dedication waiver (http://creativecommons.org/publicdomain/zero/1.0/) applies to the data made available in this article, unless otherwise stated in a credit line to the data. 


\section{Background}

Hepatitis $\mathrm{C}$ virus (HCV) causes a significant worldwide burden and infects more than 185 million people worldwide, in which 71 millions of them are chronically infected [1]. HCV infection has caused a major burden from its sequelae of chronic infection. With current direct-acting antivirals (DAA) that accomplish high sustained virological response (>95\%), WHO had pursued a goal to eradicate HCV as a public health threat by 2030 [2]. Despite having good treatment options, most of the people with $\mathrm{HCV}$ are undiagnosed, which leads to a low treatment rate. This is specifically observed in low- and middle-income countries (LMICs), such as Malaysia with limited resources and many competing health needs from its citizens to organize a full-scale, nationwide initiatives to eliminate HCV. Hence, a concept of "Micro-elimination", which entails a phased approach to achieve national elimination goals in defined segments of the population through the engagement of multistakeholders who are most knowledgeable about the needs of the specific populations to tailor interventions within these settings to eliminate $\mathrm{HCV}$ [3].

Chronic haemodialysis (HD) patients are a population that should be prioritized as they have higher HCV prevalence rate, higher risk of transmitting $\mathrm{HCV}$ to others, and readily identified by mandatory screening. Both rigorous screening and early treatment of $\mathrm{HCV}$ in HD patients are crucial in reducing the incidence and outbreak in this cohort, in line with the paradigm of "treatment as prevention" with the ultimate goal of micro-elimination of $\mathrm{HCV}$ among this cohort [3].

Anti-HCV antibody is the serological screening test for $\mathrm{HCV}$ infection which is recommended by WHO [2]. Although it is relatively simple and cheap, it creates a great challenge to detect patients in acute phase of infection due to long "window period" (range: 45-68 days for cohort of non-HD patients [4], and median of 154 days for cohort of HD patients [5]) on top of the possibility of false negative anti-HCV in immunocompromised individuals inclusive of end-stage kidney disease. A confirmatory test is required to distinguish spontaneously resolved cases from chronic infection or active HCV infections [6]. Serum HCV RNA is widely used as a confirmatory test, but HCV RNA test is expensive and requires certain amount of technical skill to avoid false positive results as well as longer turnaround time [6, 7]. Hence, a significant number of anti-HCV positive patients failed to proceed with confirmatory $\mathrm{HCV}$ tests and are often lost to follow-up, leading to a low treatment rate, especially among HD populations [8].

In contrast, $\mathrm{HCV}$ Core Antigen (HCV Ag) has been shown to be a dependable marker to diagnose active infection [9], with lower cost and shorter processing time $[6,10]$. Additionally, it is used to assess treatment response to direct antiviral agents $[9,11]$. Furthermore, in the era of new interferon-free, oral direct antiviral therapy that consists of pan-genotypic regime, $\mathrm{HCV} \mathrm{Ag}$ alone is sufficient for diagnosis of active $\mathrm{HCV}$ infection, despite its lower analytical sensitivity as compared to HCV RNA [7]. Up to date, using HCV RNA test as confirmatory test for seropositive HD patients is still the main practice worldwide [12, 13]. Most studies using $\mathrm{HCV} \mathrm{Ag}$ as a confirmatory test mainly involved general population. Although there are few studies on HCV Ag in HD cohort that show good correlation [6, 14, 15], these studies are limited and do not include Asians population, more specifically Malaysian population with multi-ethnicity. In Asia, $\mathrm{HCV} \mathrm{Ag}$ availability is limited, where Malaysia is among the countries considering $\mathrm{HCV} \mathrm{Ag}$ as an alternative to nucleic acid test. Whereas HCV Ag is still unavailable in Hong Kong or Singapore, and is relatively expensive in mainland China [13].

Recent studies have revealed that a combination of anti-HCV screening along with sequential confirmation with HCV Ag then HCV RNA on antigen negative could offer equivalent or greater diagnostic capability at a better cost. It is also a cost-effective screening algorithm to detect active $\mathrm{HCV}$ infections in high prevalence settings [16-18]. Locally, it is estimated that HCV Ag test is approximately 3 times cheaper than HCV RNA.

Hence, this study is designed to assess the correlation of HCV Ag with HCV RNA among HD cohort in our multi-ethnic population. Besides, we would like to identify the prevalence of active $\mathrm{HCV}$ viremia among $\mathrm{HCV}$ serology positive HD patients. This has important clinical implications for the planning of resource allocation to treat active $\mathrm{HCV}$ infection.

\section{Methods \\ Study design}

We conducted a cross-sectional study from July 2019 to May 2020 from 17 dialysis centres across West Malaysia. One hundred and twelve HCV seropositive patients were recruited based on their HCV serology result reported on Malaysia Dialysis and Transplantation Registry (MDTR). The inclusion criteria was End Stage Kidney Disease (ESKD) patients undergoing regular haemodialysis treatment. Refusal to participate or patients who are receiving treatment or have been treated for hepatitis $\mathrm{C}$ were excluded.

Patients' anti-HCV antibody status was obtained from dialysis centres' regular blood screening results. Patients' data, which include demographics, medical and dialysis history, laboratory tests, and concomitant medications, were collected in a standardized data collection form. 


\section{Blood sample collection}

For all consented patients, blood was taken prior to their dialysis. Both $\mathrm{HCV} \mathrm{Ag}$ and $\mathrm{HCV}$ RNA were being tested. Samples with HCV Ag 3 to $10 \mathrm{fmol} / \mathrm{L}$ would have a repeat testing using the same sample to confirm the results (Additional file 1).

\section{HCV Ag measurement}

The HCV Ag was tested with the Abbott ARCHITECT $\mathrm{HCV}$ Ag test. This is a chemiluminescent microparticle immunoassay (CMIA). It uses microparticles coated with monoclonal anti-HCV to detect the $\mathrm{HCV}$ core $\mathrm{Ag}$ (nucleocapsid pepside 22, p22). HCV Ag level of $\geq 3.00$ $\mathrm{fmol} / \mathrm{L}$ was recognised as reactive whereas level $<3$ $\mathrm{fmol} / \mathrm{L}$ was recognised as non-reactive. This cut-off level of $3 \mathrm{fmol} / \mathrm{l}$ has been shown to have high sensitivity and specificity as well as good correlation with $\mathrm{HCV}$ RNA > $3000 \mathrm{IU} / \mathrm{ml}$.

\section{HCV RNA measurement}

HCV RNA quantification was quantified with the Reverse Transcription Polymerase Chain Reaction (RTPCR) on Qiagen Artus HCV QS-RGQ kit. The lower limit of detection was $21 \mathrm{IU} / \mathrm{mL}$. Samples with $\mathrm{HCV}$ RNA level $\geq 21 \mathrm{IU} / \mathrm{mL}$ and $<21 \mathrm{IU} / \mathrm{mL}$ were reported as positive and negative, respectively. RT-PCR was considered as the gold standard method to compare the result of $\mathrm{HCV}$ Ag.

\section{Statistical analysis}

The data was analyzed, whereby the descriptive analysis was done to report the continuous variables in mean and standard deviation, and categorical variables were reported in frequency and percentage. The sensitivity, specificity, positive predictive value, and negative predictive value were calculated to determine the accuracy of HCV Ag test compared to HCV RNA as gold standard. The correlation coefficients between HCV Ag and HCV RNA were calculated using Spearman's rank test. Statistical significance was set at $p$ value less than 0.05 . Data were analyzed using SPSS for Macintosh Version 24.0 (SPSS, Inc., Chicago, IL, USA).

\section{Results}

A total of 112 patients were successfully recruited into this study. Most of the patients were males (59.8\%) with the mean age of $54.04 \pm 11.62$ years. Table 1 showed the demographic characteristics of the patients together with their primary cause of ESKD.

We analysed the $\mathrm{HCV}$ Ag test comparing to $\mathrm{HCV}$ RNA test as gold standard test, as shown in Table 2. Among $86 \mathrm{HCV}$ RNA positive subjects, 78 were $\mathrm{HCV}$ Ag positive, giving a sensitivity of $90.7 \%$ (95\% confidence interval 82.5 to $95.9 \%)$ and a specificity of $100 \%$ (95\% CI
Table 1 Demographic and clinical characteristics of 112 patients recruited

\begin{tabular}{ll}
\hline Patient Characteristics & $\begin{array}{l}\text { Frequency (\%) / } \\
\text { Mean } \pm \text { SD }\end{array}$ \\
\hline Gender & $67(59.8)$ \\
Males & $45(40.2)$ \\
Females & $54.04 \pm 11.62$ \\
Age (years) & $14.1 \pm 9.7$ \\
HD vintage (years) & \\
Ethnicity & $55(49.1)$ \\
Malay & $32(28.6)$ \\
Chinese & $24(21.4)$ \\
Indian & $1(0.9)$ \\
Others & \\
Primary Cause of ESKD & $25(22.3)$ \\
Diabetes Mellitus & $32(28.6)$ \\
Hypertension & $15(13.4)$ \\
Chronic Glomerulonephritis & $2(1.8)$ \\
Systemic Lupus Erythematous & $3(2.7)$ \\
Renal calculi/ Reflux nephropathy & $1(0.9)$ \\
Drug induced & $1(0.9)$ \\
Small kidneys & $29(25.9)$ \\
Unknown & $4(3.5)$ \\
Others & $22(19.6)$ \\
No. of patients who had RNA test prior to & \\
\hline &
\end{tabular}

86.8 to $100 \%$ ). The positive predictive value and negative predictive value were 100 and $76.5 \%$ (95\% CI 62.7 to $86.3 \%$ ) respectively, with accuracy of $92.9 \%$ (95\% CI 86.4 to $96.9 \%)$. The Spearman Correlation coefficient was $0.833(p<0.001)$.

We also analyzed the HCV Ag result according to different HCV RNA concentrations as shown in Table 3. There was total of 112 samples where 78 were $\mathrm{HCV}$ Ag reactive and 34 non-reactive. All HCV RNA level $<21$ $\mathrm{IU} / \mathrm{mL}$ were $\mathrm{HCV}$ Ag negative, whereas among $81 \mathrm{HCV}$ RNA level $>3000 \mathrm{IU} / \mathrm{mL}, 95.1 \%$ of those were $\mathrm{HCV} \mathrm{Ag}$ positive. Of the $4 \mathrm{HCV}$ Ag negative samples, they have HCV RNA level of 5400, 11,970, 13,770, and 24,840 IU/ $\mathrm{mL}$ respectively.

Within the HCV RNA level of $22-2999 \mathrm{IU} / \mathrm{mL}$, only one out of five was $\mathrm{HCV}$ Ag positive. The positive $\mathrm{HCV}$ Ag samples had HCV RNA level of $500 \mathrm{IU} / \mathrm{mL}$ whereas the four HCV Ag negative samples had HCV RNA level was $180,540,630,1980 \mathrm{IU} / \mathrm{mL}$ respectively.

$\mathrm{HCV}$ RNA and HCV Ag both showed a significant correlation at level above $3000 \mathrm{IU} / \mathrm{mL}$. The Spearman test showed a higher correlation with a correlation coefficient of $0.897(p<0.001)$. 
Table 2 Comparison between HCV Ag \& HCV RNA test

\begin{tabular}{llll}
\hline HCV Ag test result & \multicolumn{2}{l}{ HCV RNA test result } & Total \\
\cline { 2 - 3 } & Positive & Negative & \\
\hline Reactive & 78 & 0 & 78 \\
Non-reactive & 8 & 26 & 34 \\
Total & 86 & 26 & 112 \\
\hline
\end{tabular}

Among the 8 false negative HCV Ag result, all patients had normal liver function test.

\section{Discussion}

This study indicates a good correlation between the index test, $\mathrm{HCV} \mathrm{Ag}$ with the gold standard HCV RNA among haemodialysis population. Among 112 anti-HCV seropositive samples, $\mathrm{HCV}$ Ag was positive in $90.7 \%$ of samples tested positive for HCV RNA. HCV Ag had 8 $(9.3 \%)$ false negative cases and $0(0.00 \%)$ false positive cases at the cutoff point of $3 \mathrm{fmol} / \mathrm{L}$. This gives a specificity of $100 \%$ and a sensitivity of $90.7 \%$. A lower detection rate compared to HCV RNA is consistent with previous studies [7, 9, 10, 17, 19]. Both HCV Ag and HCR RNA tests showed a significant correlation, with Spearmen test coefficient of $0.833(p<0.001)$. Our result was reported qualitatively as reactive if HCV Ag value exceeds $3 \mathrm{fmol} / \mathrm{L}$ and the correlation result was similar compared to previous studies that reported HCV Ag quantitatively $[6,14]$.

Furthermore, HCV Ag showed a higher sensitivity rate of $95.1 \%$ at greater HCV RNA level $(>3000 \mathrm{IU} / \mathrm{mL})$. The correlation at HCV RNA level above $3000 \mathrm{IU} / \mathrm{mL}$ was higher, with Spearman test coefficient of $0.897(p<$ $0.001)$. This was similar to the other studies $[6,10]$, where the sensitivity of $\mathrm{HCV} \mathrm{Ag}$ increased in higher HCV RNA concentration levels. Among the 4 false negative cases with HCV RNA level $>3000$, the HCV RNA levels ranged between 5400 to $24,840 \mathrm{IU} / \mathrm{mL}$, which might be attributed to the types of genotype, as seen in other studies [20, 21].

According to Trevizoli et al., HCV RNA levels tend to be lower in patients on long term HD compared to patients with normal renal function [22], which has led to the concern on the suitability of $\mathrm{HCV}$ Ag in diagnosing active $\mathrm{HCV}$ infection among $\mathrm{HD}$ population as the

Table 3 Comparison of HCV Ag among different HCV RNA concentrations

\begin{tabular}{llll}
\hline HCV RNA Level (IU/mL) & \multicolumn{2}{l}{ HCV Ag Test } & Total \\
\cline { 2 - 3 } & Reactive & Non-reactive & \\
\hline$<21$ & 0 & 26 & 26 \\
$22-2999$ & 1 & 4 & 5 \\
$>3000$ & 77 & 4 & 81 \\
Total & 78 & 34 & 112 \\
\hline
\end{tabular}

sensitivity of HCV Ag depends on the RNA level [23]. In our study, the median HCV RNA level was 175,455 IU/ mL, with only five cases had HCV RNA below $3000 \mathrm{IU} /$ $\mathrm{mL}$. Considering the relatively high viral load among most patients, $\mathrm{HCV}$ Ag could potentially be used as another method to diagnose active HCV infection in HD population.

Of those with HCV RNA level less than $3000 \mathrm{IU} /$ $\mathrm{mL}, \mathrm{HCV}$ Ag was positive in only one sample. HCV RNA for the five samples ranged from 180 to 1980 $\mathrm{IU} / \mathrm{mL}$, which was much lower compared to $3000 \mathrm{IU} /$ $\mathrm{mL}$ where $\mathrm{HCV} \mathrm{Ag}$ correlated best with $\mathrm{HCV}$ RNA. The four false negative results with HCV RNA level lower than $3000 \mathrm{IU} / \mathrm{mL}$, and the four false negative results with HCV RNA level higher than $3000 \mathrm{IU} / \mathrm{mL}$, have normal liver function test. Hence, all eight results would require a confirmatory molecular RNA testing to resolve this result. In view of the $100 \%$ specificity, only $\mathrm{HCV}$ Ag negative results require further evaluation by HCV RNA. This would confirm the active infections and determine those who are potential candidates for DAA treatment [19, 24-26].

As far as we can tell, our study is the first study utilizing ARCHITECT HCV Ag test involving Asian populations with the largest $\mathrm{HCV}$ seropositive sample size (112) among HD population. It showed that HCV Ag correlates well with HCV RNA in Asian population. However, our study has several limitations. Firstly, despite the largest HCV seropositive study among HD population, the sample size is still rather small. The data on HCV genotype is lacking and may account for the false negative HCV Ag result, particularly amongst those with HCV RNA of higher than $3000 \mathrm{IU} / \mathrm{mL}[20,21]$.

$\mathrm{HD}$ population poses a higher risk of $\mathrm{HCV}$ infection as compared to the general population. In Malaysia, the prevalence of $\mathrm{HCV}$ seropositive among HD population is $2 \%$, in comparison to $0.98 \%$ in the general population $[27,28]$. From our study, the prevalence of active $\mathrm{HCV}$ viremia among HD population is $76.8 \%$ among those who are anti-HCV positive. This finding is similar to Jasuja et.al who reported $72.7 \%$ of active HCV viremia among HCV seropositive HD population [29].

High prevalence of active $\mathrm{HCV}$ viremia among $\mathrm{HD}$ population is associated with greater risk of HCV transmission. In this study, we demonstrated that only $19.6 \%$ (22/112) of HCV seropositive patients have had previous HCV RNA testing. Lack of HCV confirmation poses a great challenge in managing $\mathrm{HCV}$ infection and achieving micro-elimination in the $\mathrm{HD}$ population. As a LMICs, high cost of HCV confirmatory testing, as well as limited use of HCV DAA therapy in chronic kidney disease patients, was believed to be the major reasons for poor $\mathrm{HCV}$ treatment uptake amongst patients with advanced CKD [6, 23]. 
Based on our study, HCV Ag provides a suitable alternative to HCV RNA due to its lower cost and fast analytical process (within 40 mins) and therefore, short turnaround time $[15,19,23]$. We suggest initial screening by Anti-HCV Ab followed by $\mathrm{HCV}$ Ag test for seropositive HD cohorts. For seropositive HD patient with negative $\mathrm{HCV} \mathrm{Ag}$, we recommend to follow-up with HCV RNA test as it has negative predictive value of 76.5\%. This algorithm, as proposed by Julicher et al. [16], and Wasitthankasem et al. [17], could potentially be cost-effective as not all seropositive HD patient is subjected to expensive RNA test. This would be a thought-provoking domain for a future study.

\section{Conclusion}

$\mathrm{HCV} \mathrm{Ag}$ is sensitive and specific to diagnose chronic active $\mathrm{HCV}$ infection among haemodialysis patients. Hence, HCV Ag test can be included in the current diagnostic guideline along with anti-HCV and $\mathrm{HCV}$ RNA to diagnose chronic active HCV infection among haemodialysis population. This would allow clinician to identify patients eligible for $\mathrm{HCV}$ treatment effectively and efficiently.

\section{Supplementary Information}

The online version contains supplementary material available at https://doi. org/10.1186/s12882-020-02154-4.

Additional file 1. Testing algorithm; Algorithm of different HCV Ag level and requirement required to repeat testing.

\section{Abbreviation}

CMIA: Chemiluminescent microparticle immunoassay; DAA: Direct-acting Antiviral; HCV: Hepatitis C Virus; HCV Ab: Anti-HCV Antibodies; HCV Ag: HCV Core Antigen; HCV RNA: HCV Ribonucleic acid; HD: Haemodialysis; LMICs: Low- and middle-income countries; NPV: Negative Predictive Value; PCR: Polymerase Chain Reaction; PPV: Positive Predictive Value; WHO: World Health Organization

\section{Acknowledgements}

We would like to acknowledge the HD centres, the staffs, and patients who had agreed to participate in our study.

\section{Authors' contributions}

Study conception and design: XZW, CCG, RM, RY, SST, SKL. Data collection: XZW, RY. Data analysis and interpretation: XZW, SKL, SG. Drafting of manuscript: XZW. Critical revision: CCG, RM, RY, SST, SG, SKL. All authors have read and approved the final manuscript.

\section{Funding}

This work was supported by Research Grant from National Kidney Foundation and Malaysia Society of Nephrology. The funding bodies played no role in the design of the study, collection, analysis, and interpretation of data and in writing the manuscript.

\section{Availability of data and materials}

The datasets used and/or analysed during the current study are available from the corresponding author on reasonable request.

\section{Ethics approval and consent to participate}

Approval from the University Malaya Medical Research Ethics Committee (UMMC EC approval number: 2018128-5989) and National Medical Research
Register (NMRR-18-2820-39944 IIR) was obtained before commencement of the study. Written consent to participate has been obtained from all patients who agreed to participate in the study.

\section{Consent for publication}

Not applicable.

\section{Competing interests}

This study does not present any competing of interest for the authors.

\section{Author details}

${ }^{1}$ Department of Medicine, Faculty of Medicine, University of Malaya, Jalan University, 50603 Kuala Lumpur, Malaysia. ${ }^{2}$ Hospital Kuala Lumpur, Jalan Pahang, 50586 Kuala Lumpur, Malaysia. ${ }^{3}$ National Institutes of Health, Ministry of Health, Kompleks Institut Kesihatan Negara (NIH), No. 1, Jalan Setia Murni U13/52 Seksyen U13, Setia Alam, 40170 Shah Alam, Selangor, Malaysia. ${ }^{4}$ Selayang Hospital, B21, Lebuhraya Selayang - Kepong, 68100 Batu Caves, Selangor, Malaysia. ${ }^{5} 8 \mathrm{TE}$, Menara Timur, Pusat Perubatan Universiti Malaya, Jalan Universiti, Lembah Pantai, 50603 Kuala Lumpur, Malaysia.

Received: 3 June 2020 Accepted: 5 November 2020

Published online: 13 November 2020

\section{References}

1. Blach $\mathrm{S}$, et al. Global prevalence and genotype distribution of hepatitis $C$ virus infection in 2015: a modelling study. Lancet Gastroenterol Hepatol. 2017;2(3):161-76.

2. World Health Organization, World Health Organization, and Replacement of (work) World Health Organization., Guidelines for the screening care and treatment of persons with chronic hepatitis C infection. https://www.who. int/hepatitis/publications/hepatitis-c-guidelines-2018/en/.

3. Lazarus $\mathrm{JV}$, et al. The Micro-Elimination Approach to Eliminating Hepatitis C: Strategic and Operational Considerations. Semin Liver Dis. 2018;38(3):181-92.

4. Glynn SA, et al. Dynamics of viremia in early hepatitis C virus infection. Transfusion. 2005;45(6):994-1002.

5. Sypsa $V$, et al. Incidence and patterns of hepatitis $C$ virus seroconversion in a cohort of hemodialysis patients. Am J Kidney Dis. 2005;45(2):334-43.

6. Miedouge M, Saune K, Kamar N, Rieu M, Rostaing L, Izopet J. Analytical evaluation of HCV core antigen and interest for HCV screening in haemodialysis patients. J Clin Virol. 2010;48(1):18-21.

7. Chevaliez S, Soulier A, Poiteau L, Bouvier-Alias M, Pawlotsky JM. Clinical utility of hepatitis $C$ virus core antigen quantification in patients with chronic hepatitis C. J Clin Virol. 2014;61(1):145-8.

8. Rongey CA, Kanwal F, Hoang T, Gifford AL, Asch SM. Viral RNA testing in hepatitis C antibody-positive veterans. Am J Prev Med. 2009;36(3):235-8.

9. Lamoury FMJ, et al. Hepatitis C virus core antigen: a simplified treatment monitoring tool, including for post-treatment relapse. J Clin Virol. 2017;92:32-8.

10. Freiman $\mathrm{JM}$, et al. Hepatitis $\mathrm{C}$ core antigen testing for diagnosis of hepatitis $C$ virus infection: a systematic review and meta-analysis. Ann Intern Med. 2016;165(5):345-55.

11. Mederacke I, et al. Different kinetics of HBV and HCV during haemodialysis and absence of seronegative viral hepatitis in patients with end-stage renal disease. Nephrol Dial Transplant. 2011;26(8):2648-56.

12. Jadoul $M$, et al. Prevalence, incidence, and risk factors for hepatitis $C$ virus infection in hemodialysis patients. Kidney Int. 2019;95(4):939-47.

13. Li PKT, et al. 2018 Kidney Disease: Improving Global Outcomes (KDIGO) Hepatitis C in Chronic Kidney Disease Guideline Implementation: Asia Summit Conference Report. Kidney Int Reports. 2020;5(8):1129-38.

14. Mederacke I, et al. HCV core antigen testing in HIV- and HBV-coinfected patients, and in HCV-infected patients on hemodialysis. J Clin Virol. 2012; 53(2):110-5.

15. Li Cavoli G, et al. Hepatitis C virus Core antigen test in monitoring of Dialysis patients. Hepat Res Treat. 2012;2012:1-4

16. Jülicher $P$, Galli C. Identifying cost-effective screening algorithms for active hepatitis C virus infections in a high prevalence setting. J Med Econ. 2018; 21(1):1-10.

17. Wasitthankasem $\mathrm{R}$, et al. HCV core antigen is an alternative marker to HCV RNA for evaluating active HCV infection: implications for improved diagnostic option in an era of affordable DAAs. PeerJ. 2017;2017:11. 
18. Chakravarti A, Chauhan MS, Dogra G, Banerjee S. Hepatitis C virus core antigen assay: can we think beyond convention in resource limited settings? Brazilian J Infect Dis. 2013;17(3):369-74.

19. Alonso R, Pérez-García F, López-Roa P, Alcalá L, Rodeño P, Bouza E. HCV core-antigen assay as an alternative to HCV RNA quantification: a correlation study for the assessment of HCV viremia. Enferm Infecc Microbiol Clin. 2018; 36(3):175-8.

20. Nguyen LT, et al. Hepatitis $C$ virus core mutations associated with falsenegative serological results for genotype 3a core antigen. J Clin Microbiol. 2015;53(8):2697-700

21. Garbuglia AR, et al. HCV core antigen and HCV-RNA in HIV/HCV co-infected patients with different HCV genotypes. BMC Infect Dis. 2014;14:222.

22. Trevizoli JE, et al. Hepatitis $\mathrm{C}$ is less aggressive in hemodialysis patients than in nonuremic patients. Clin J Am Soc Nephrol. 2008;3:1385-90.

23. Goel A, Bhadauria DS, Aggarwal R. Hepatitis C virus infection and chronic renal disease: a review. Indian J Gastroenterol. 2018;37(6):492-503.

24. Tillmann $\mathrm{HL}$. Hepatitis $\mathrm{C}$ virus core antigen testing: role in diagnosis, disease monitoring and treatment. World J Gastroenterol. 2014;20:6701-6.

25. Galli C, Julicher P, Plebani M. HCV core antigen comes of age: a new opportunity for the diagnosis of hepatitis C virus infection. Clin Chem Lab Med. 2018;56(6):880-8.

26. Hadziyannis E, Minopetrou M, Georgiou A, Spanou F, Koskinas J. Is HCV core antigen a reliable marker of viral load? An evaluation of HCV core antigen automated immunoassay. Ann Gastroenterol. 2013;26:146-9.

27. Wong HS, Goh BL. 24th Report of the Malaysian Dialysis \& Transplant 2016; 2018

28. Rahman F et al. At the Edge of a Miracle: The Hepatitis C Virus (HCV) Epidemic in Malaysia: A Situational Report. https://www.aidsdatahub.org/ resource/edge-miracle-hcv-epidemic-malaysia-situational-report.

29. Jasuja $\mathrm{S}$, et al. Prevalence and associations of hepatitis $\mathrm{C}$ viremia in hemodialysis patients at a tertiary care hospital. Indian J Nephrol. 2009; 19:62-7.

\section{Publisher's Note}

Springer Nature remains neutral with regard to jurisdictional claims in published maps and institutional affiliations.

Ready to submit your research? Choose BMC and benefit from:

- fast, convenient online submission

- thorough peer review by experienced researchers in your field

- rapid publication on acceptance

- support for research data, including large and complex data types

- gold Open Access which fosters wider collaboration and increased citations

- maximum visibility for your research: over $100 \mathrm{M}$ website views per year

At $\mathrm{BMC}$, research is always in progress.

Learn more biomedcentral.com/submissions 